\title{
The ministry of Beyers Naude to the victims of oppression 1960-1994: A challenge to Christian mission in post-apartheid South Africa
}

\author{
Authors: \\ Tobias Masuku $u^{1,2,3}$ \\ Nelus Niemandt ${ }^{1}$ \\ Affiliations: \\ ${ }^{1}$ Department of Science of \\ Religion and Missiology, \\ University of Pretoria, \\ South Africa \\ ${ }^{2}$ Religious Policy and \\ Planning, Department of \\ Defence, Pretoria, \\ South Africa \\ ${ }^{3}$ Uniting Reformed Church \\ in Southern Africa (URCSA), \\ Delmas, South Africa \\ Correspondence to: \\ Nelus Niemandt \\ Email: \\ nelus.niemandt@up.ac.za \\ Postal address: \\ Private bag X20, Hatfield, \\ Pretoria 0028, South Africa \\ Dates: \\ Received: 18 Jan. 2011 \\ Accepted: 21 Sept. 2011 \\ Published: 08 Feb. 2012 \\ How to cite this article: \\ Masuku, M.T. \& Niemandt, \\ C.J.P., 2012, 'The ministry of \\ Beyers Naude to the victims \\ of oppression 1960-1994: \\ A challenge to Christian \\ mission in post-apartheid \\ South Africa', Verbum et \\ Ecclesia 33(1), Art. \#494, \\ 7 pages. http://dx.doi. \\ org/10.4102/ve.v33i1.494
}

(C) 2012. The Authors. Licensee: AOSIS OpenJournals. This work is licensed under the Creative Commons Attribution License.
Dr Beyers Naudé's ministry to the victims of apartheid between 1960-1994 was of missionary significance. His mission challenged the conservative or stereotype mission approaches of the church which were in line with the thinking of Edinburgh 1910. Dr Beyers Naudé in contrast, applied the spirit of Tambaram 1938 supporting what Saayman termed a 'comprehensive ministry'. His ministry challenged the mission of the church in post-apartheid South Africa during which the prophetic voice of the church has diminished and Ministers of Religion who were vocal against government injustices during Beyers Naudé's ministry are supporting the current post-apartheid South African government.

\section{Introduction}

The article argues that Beyers Naudé's ministry during the apartheid rule in South Africa (SA) brought a missionary dimension to the victims of apartheid. These victims are people who were disillusioned by the Christian faith as a result of the way in which it was misused as a tool for oppression (Ryan 2005:v). He uniquely communicated the Christian message to these victims in such a way that whilst they initially doubted and rejected this religion, they ultimately embraced it because he touched them through his ministry (Ryan 2005:vi).

This article seeks to indicate that Beyers Naudé's ministry in SA, had vast missiological implications. He served as an example of the best attributes of the Christian faith at a time when the Christian witness was at risk. The purpose of this article is therefore to unearth the reason as to what 'muthi' (or magic) he used to win the hearts and love of the victims of oppression, and thus bring back the credibility of this religion. Archbishop Emeritus Desmond Tutu wrestled with similar questions regarding Beyers Naudé's miraculous acceptance by the victims of apartheid:

How could such an unlikely candidate, such a quintessential NG, who saw nothing wrong with apartheid and who opposed supporting Britain against Hitler in World War II, have become a man who could be appointed General Secretary of the South African Council of Churches without anyone raising an eyebrow or being outraged? What had happened to effect what seemed such an extraordinary metamorphosis? For as a supporter of apartheid, which had been declared a heresy by SACC following the epoch-making declaration by WARC in 1982, he would have been total anathema, someone that the organization would not have wished to touch with the proverbial barge pole, especially as the Church to which he belonged then had left the SACC two decades previously. What had happened? (Tutu 2005:48)

We are going to approach this topic by looking at Naudés mission field, in other words the political landscape of SA during this period, the centripetal and centrifugal aspects of his ministry, apartheid victims' response to his ministry and the way in which the church failed to carry out his ministry legacy today.

\section{An overview of Beyers Naudé's mission field SA political landscape during the period under review}

In South Africa, the years 1960-1977 saw untold developments in socio-political and economic areas. This was the period during which apartheid was applied in the lives of millions of South Africans and where the ideology and theology of apartheid were developed in all circles. The decade started with the traumatic events at Sharpeville when a great number of Black people openely took action against apartheid. (Heaney 2004:49, [authors' own translation])

This period starts from Naudé's 'conversion' in the early 1960s onwards when in 1963 he got involved in what Meyer (2006:124) referred to as his 'public career', meaning his ministry to the entire SA, especially victims of apartheid. It was marked by turbulent action, vibrancy and violence on the side of the apartheid victims in their response to apartheid violence. The adoption of an armed struggle was made during this period. This period also saw participants in 
the struggle dominated by the youth, some of whom where inexperienced in terms of military practice. Their level of inexperience led Ellis and Sechaba (1992:33) to describe them as 'the army of amateurs, hardly any of whom had knowledge of weapons. Some of them caused civilian casualties and even blew themselves up with their homemade bombs.' The state, on the other side, was more brutal in terms of torture to the victims of oppression and all who opposed it. The ministry of Beyers Naudé zoomed into this most difficult period in SA based on the nature of the political climate. The struggle participants transformed from dignified adults in formal suits and hats during protest matches in the 1950s into that of young people, stone throwing 'comrades', in the mid-1970s (International Defence and Aid Fund for Southern Africa, 1988).

Most of the legislation passed during the late 1940s and the entire 1950s were fully implemented and operational. The difference between these periods in terms of political dynamism, regarding the freedom struggle by the then dominant freedom organisation, the ANC, has also been noted by Dubow (2000:85) when he wrote that the 1980s were not the 1950s, and the domestic political landscape which the ANC confronted was infinitely more complex and crowded than it had been twenty years earlier'. Meyer (2006:124) regarded this period as one of crisis in the life of Beyers Naudé. He outlined the different perspectives for both Black and White South Africans regarding the political situation in the country. He stated that for Whites it was a 'Christian' Separate Development and for Blacks it was an 'unchristian' apartheid. The climax of this period was during the 1980s, which Saayman (2009) describes as follows:

The mid-eighties of the previous century in SA marked the high point of the struggle against apartheid in SA. It was the time when everything was conceived in terms of the 'total onslaught' of the liberation movement against the illegitimate state, and the 'total strategy' of the state to overcome the 'terrorist' onslaught. (p. 12)

Beyers Naudé's ministry to SA was understood by him as part of his mission responsibilities to God. He regarded himself as the subject of God's mission. He had a strong interest in mission and evangelism. His deep interest in mission was personally articulated in the interview conducted by Prof Lammert Leertouwer between him and Dr Dorothee Solle on 20 June 1986. When explaining factors that led to his 'conversion' he stated:

'The first is a theological one. When, after the Second World War, in looking at what was happening in Africa, the whole process of decolonization, freedom, political freedom, coming to Africa, the cry of millions of Africans throughout the continent to throw off the yoke of colonialism, with my deep interest in mission, in evangelism, and in the youth work of the church, I asked myself: 'what does this say to us in South Africa?' (WCC 1986:4-5)

In order to fully understand the ministry of Beyers Naudé, which he understood as 'the hand of God guiding me into a new direction' (WCC 1986:6), we have divided his ministry along the lines of centripetal and centrifugal mission patterns.

\section{Centripetal mission pattern of Beyers Naudé}

Beyers Naudé's ministry made him a 'magnet' that pulled people to him. Because of this 'attraction', his house or office was inundated with people who needed advice and counselling. They followed him wherever he went especially during the years of his banning order. Randall (1982:42) wrote about Beyers Naudé that 'even in his present situation he must believe that he is giving a witness to God's word'. Most of the people who came to him were victims of apartheid. One such person was Reverend Farisani, former the Member of Executive Council (MEC) for transport and speaker of the Limpopo Legislature (Naudé 1995:111).

Beyers Naudé did not only attract the locals in SA but also the international community. Countries from which people paid him visits included the Netherlands, Germany, Britain, USA, Canada and other African countries (Naudé 1995:121). The situation is described by Randall (1982) as:

(...) a steady stream of visitors find their way to his modest suburban house in Johannesburg- ambassadors, foreign church dignitaries, journalists, and even the American writer James Michener, who claims that Naudé was the prime inspiration for his novel on South Africa, The Covenant. (p. 42)

The location of the offices of the Christian Institute (CI) in Braamfontein to which Beyers Naudé was a director, was of strategic importance in sending out a message of a non-racial society. Beyers Naudé strategically chose his ministry centres in cities or urban areas. Bosch (1991:129-131) also described the biblical St. Paul's choice of mission centres as strategic in the sense that it was also urban in terms of what he (Bosch) calls 'metropolises'.

Another aspect of the character of the ministry of Beyers Naudé was reflected in the way in which he shaped his staff at the CI. Beyers Naudé turned the staff of the CI into a model of a 'true' community. It was converted into a community of equals in a number of respects, where members were respected as human beings. It was a community whose respect for one another ran across gender, age, economic class and racial lines. It was not necessarily a homogenous community in all respects but a 'collection of radicals, agnostics and demure servants of the gospel' (Randall 1982:45).

Beyers Naudé's ministry also attracted the media. They came to him for interviews and constantly reported about him. For this reason 'he continues to feature prominently in the media' (Randall 1982:42). The English and Afrikaans media differed in their reporting about Beyers Naudé. For instance:

(...) to the English press he was a courageous, popular figure, a man who has been martyred and maligned by the Afrikaans community. The Afrikaans press portrayed him as a troublesome, controversial man with many new and suspect 'communist' or liberalistic' views (...).The English press depicted him as the target of unfair victimization while the Afrikaans press, through several hostile reports and letters, conveyed the impression that he was probably getting what he deserved. (Ryan 2005:99) 
Beyers Naudé was inundated with visits from the Dutch Reformed Church (DRC) missionaries who were working in Black 'daughter' churches of the DRC. The aim of their visits was to ask for advice on how to minister to the Black congregations that were made out of the three 'daughter' churches of the DRC namely the Dutch Reformed Church in Africa, the Dutch Reformed Mission Church and the Reformed Church in Africa (RCA) (Adonis 2005:120-121).

The ministry of Beyers Naudé attracted people to him for interviewing purpose. Some reflected on his ministry in the form of writing books. Amongst those who paid him visits for this reason was the unnamed person described by Randall (1982:32) as his American biographer and Alan Paton. The American biographer 'compares his awakening with the transformation of Saul of Tarsus' (Ibid). On the other hand, Alan Paton (in Ibid) wrote:

One is forced to conclude, because one does not reach such a conclusion lightly, that this is the work of the Holy Spirit and that Beyers Naudé was struck down on some Damascus road. (ibid)

Beyers Naudé also gave a lesson on his theology of religions. He did not have a conservative approach to other religions. His flexibility was seen in his attitude towards adherents of other faiths and how he shaped the community of the CI. The CI team under Beyers Naudé was defined in terms of being 'heterogeneous' (Randall 1982:45) not only on matters of race and gender but also because of their multi-religious mix. Randall (ibid) continued to indicate that in the CI the contributions of non-Christians were readily accepted if they brought new and valuable insights'.

In the light of the aforementioned scenario, Beyers Naudé embraced the Enlightenment approach regarding the question of theology of religions. Before this period, the attitude from the Catholics was that of 'outside the church no salvation', and from the Protestants 'outside the word, no salvation' (Knitter 1985:135; cf. Bosch 1991:475). Adherents of other faiths were seen as an archenemy to Christianity. But the situation changed during the Enlightenment. The Enlightenment paradigm embraced a relativistic attitude regarding other faiths which were not Christian. People valued facts for their survival rather than the world of values as prescribed by religion. Religion was pushed to the periphery. Karl Marx rejected religion and called it the 'opiate of the people', and visualised a world without religion (Bosch 1991:475).

Beyers Naudé subscribed to the Enlightenment relativistic attitude regarding theology of religions. But having said that, he cannot, judged by the level of his spirituality, subscribe to the Marxist attitude of religion especially the fact that he 'propagated the world in which it would have no place' (Bosch 1991:475).

\section{Centrifugal mission pattern of Beyers Naudé}

Beyers Naudé was not only a 'magnet' that drew people to him but travelled a lot as a result of the invitations he received.
One highlight of these invitations was one from Europe to preach in Westminster Abbey (Randall 1982:36). During his years of banning order, he continued to witness mostly as per invitation despite the frustrations and difficulty associated with the order. The ambivalence and frustrations associated with the right to witness the gospel message is outlined by Randall (1982) regarding Beyers Naudé as follows:

The legal position regarding preaching is unclear and Beyers Naudé has accepted several invitations to preach since his banning. These have come particularly from the Anglican and Presbyterian Churches. When he preaches he leaves the church immediately after the service, since it would be illegal for him to greet the congregation as they leave, any form of gathering at which social intercourse takes place is prohibited. (p. 41)

This situation exposes the frustrations brought about by the difficult context under which Beyers Naudé ministered. Beyers Naudé's ministry was also frustrated by the DRC. This became clear as there were some DRC congregations that invited him to preach and address their members on a number of issues. An example of this is his invitation to the congregation of Belgravia, Johannesburg in 1965. This visit turned violent when some of the members blocked the gates to the church building (Naudé 1995:79).

Beyers Naudé was also invited to the DRC 'daughter' churches. The invitation came from DRC ministers who were ministering as missionaries in those 'daughter' churches. Beyers Naudé had an opportunity to meet their congregations, church councils, individual members of the congregations and their families (WCC 1986:6-7).

There were; however, other visits by Beyers Naudé which had positive characteristics. One example of this is the invitation by the African Initiated Churches (AICs). This saw him paying visits to both the Transkei and Ciskei to look at the situation of AICs (Naudé 1995:83). His ministry also included prison visits to Black political leaders. This was epitomised by his visit to Steve Biko, the father of the Black Consciousness movement three months before his death. The visit took place in June 1976 in King William's Town (Naudé 1995:107).

Beyers Naudé's ministry could be described as ministry by presence. This reminds one of the incarnational lifestyle of Jesus Christ which is best described by Hirsch (2006:133) regarding the manner in which we should practice the ministry of presence and of inserting ourselves in the communities we serve. He argued that incarnation qualifies the actions of both God and his followers in the world. God reached the world by incarnating himself in Jesus. Judged by this act, God's followers in the world should be incarnational based on his example.

In the same breath Hirsch (ibid) emphasizes the importance of presence regarding mission. In his understanding, presence underlines the importance of relationships in mission. He stressed the importance of being directly present with the people. In doing this he warned that the lives of Christians 
are their messages. He reminded us that Jesus spent time with people that some Christians would feel comfortable with. The Christian presence amongst them conveys the message that God loves them too (2006:134).

Beyers Naudé's ministry by presence was seen in a number of situations in which the victims of oppression found themselves. Archbishop Emeritus Desmond Tutu correctly captured this when he stated that:

(...) when the negotiations came to bring an end to the injustice and oppression of apartheid, he was among the African National Congress delegation. He was chosen as a midwife to bring the dispensation of democracy to birth, this one who has been so long ostracized (...).When Madiba (former President Nelson Mandela) was celebrating his $80^{\text {th }}$ birthday and his marriage in 1998, we sat at the main table with Beyers, and it was an extraordinary moment. There we were, sitting side by side with some of the most extraordinary stalwarts of our struggle. (Ryan 2005:vi)

Beyers Naudé was also very much involved in ecumenism (Pro Veritate 15 May 1966:5; cf. Pro Veritate 15 May 1965:5). He even extended the element of ecumenism by including the AICs which were placed at the periphery of the main stream of Christianity (Naudé 1995:83; cf. Ryan 2005:102). The CI played an important role in the creation of the South African Council of Churches (SACC) (Randall 1982:46; cf. Pro Veritate 15 September 1966:50). Beyers Naudé was also the General Secretary of the SACC, after Archbishop Desmond Tutu, from 1985 to 1988 (Ackermann 2005:67). According to Heaney (2004:200), this afforded him an opportunity to meet with Black youth in different SACC regions who questioned the credibility of the Christian faith in the light of their plight and the misuse of this faith by the state to oppress them.

Beyers Naudé also dedicated his ministry efforts in the development of Black leadership. This was apparent in his relationship with the leadership of some liberation movements and Black church leaders. During 1973 Beyers Naudé was driving the CI into a period of closer contact with Black liberation movements with a view to prepare for the situation where Blacks would ultimately take leadership positions (Randall 1982:60).

Beyers Naudé's mission was to expose the DRC's justification of apartheid. His ministry bore an element of fairness, bravery and objectivity as epitomised by his exposure of injustice, no matter where it came from. This has been demonstrated by his unwavering exposure to the injustices as meted out by his own church and people without bias or fear. In his own words he declared:

I appeal to the white clergy of our Afrikaans churches, who in some way or another have privately expressed their deep concern about the turn for the worse which human relations are taking in our country, to come into the open and to speak, as men of God, with a prophetic voice to inform and enlighten our Afrikaans people about what really is at stake. (Naudé 2005:98)

Randall (1982:46) indicated that Beyers Naudé's ministry to the people of SA from the 1960s to the 1970s was dominated by the exposure of the 'false theological argument used by the NGK to justify apartheid' (ibid; cf. Pro Veritate 15 October 1966:2; cf. Pro Veritate 15 March 1967:1; see Pro Veritate 15 August 1966). At some stage, Beyers Naudé put in focus the integrity of the DRC as a church in the light of her biblical justification of apartheid (Pro Veritate 15 December 1966:2). He also lamented the fact that the stance of this church on apartheid makes it difficult for its ministers to be trusted in their Christian witness (Pro Veritate 15 July 1966). Beyers Naudé (2005) therefore had churches such as the DRC in mind when he stated that:

(...) I say this with regret, that in a number of instances the Christian church actively sided with the ecclesiastical, political, social or economic status quo, and even went further by actively opposing and rejecting the efforts of those who were deeply concerned to achieve social justice and full human rights for oppressed individuals and communities. (p. 111)

Beyers Naudé did not only support, but also played an important role in the formulation of what came to be called 'the message to the people of SA' in September 1968 (Randall 1982:35). He acknowledged the partnership between the CI and the SACC in the creation of the message when he stated that '... the cooperation with the South African Council of churches led to the decision of issuing the 'Message to the people of South Africa in 1968' (Naudé 1995:86, [authors' own translation]).

Beyers Naudé, in his ministry, supported the concept of military conscientiousness objection and blessed the military offensive by victims of apartheid as a 'just-war' in self defense against state violence (in Randall 1982:62). He started with the process of debates concerning this subject long before it was officially adopted by the SACC.

In 1974 a conference was held in Hammanskraal with the aforementioned subject as part of the conference resolution. The CI since 1973 started with the violence versus nonviolence debate. When it came to the SACC Hammanskraal conference, Beyers Naudé supported the conscientious objection in such a way that he even seconded the conference resolution that was dominated by it (Randall 1982:37, 61; cf. Naudé 2005:91). In simple terms, the Hammanskraal resolution 'called upon Christians to consider becoming conscientious objectors. Quite simply, to accept military service in defense of injustice was not permissible' (Randall 1982:61).

Beyers Naudé was instrumental in the creation of the Belydendekring. The Belydendekring became a formidable challenge to the DRC on its racist policy (Randall 1982:46; 1995:94; see Naudé 2005:128-130). It called, amongst other things, for the unity of the DRC family.

In March 1980, Beyers Naudé joined the congregation of the Dutch Reformed Church in Africa (DRCA) in Alexandra. In 1987 he was licensed as a minister in this church. Beyers Naudé chose Alexandra because this suburb of Greenside 
fell under the boundaries of the congregation in Alexandra (Naudé 1995:119; cf. Randall 1982:42).

The ministry of Beyers Naudé also embraced the 'despised' AICs (Pro Veritate 15 July 1965:5). He assisted them with theological education as well as the establishment of their organisation called the African Independent Churches Association (AICA) which was launched in Queenstown in June 1965 (Hayes 2006:59; cf. Naudé 1995:83; see Ryan 2005:102).

Beyers Naudé accepted an invitation back to the DRC in the early 1990s as a member of his last congregation of Aasvoëlkop. He passed away in 2004 and was honoured by the victims of oppression with a state funeral.

\section{Positive response to the ministry of Beyers Naudé}

The ministry of Beyers Naudé greatly touched and impressed the victims of apartheid, some of whom assumed senior government positions in post apartheid South Africa. The impression did not exclude those who occupied the highest office in the country like the president of post-apartheid South Africa. Nelson Mandela (Ancer \& Kgosana 2004) knew Beyers Naudé as the anti-apartheid cleric who achieved much in his life and whose work has been a source of inspiration for South Africa. After learning that Beyers Naudé passed on, Mandela cut short his visit in Mozambique and returned to South Africa without delay, to comfort the Naudé family.

Thabo Mbeki (Vani Nair 2004) stated that had it not been for Beyers Naudé, history books would have told a different story of hatred, fear and loathing for South Africa. He added that Beyers Naudé had called on all South Africans to understand that the reconciliation needed for peace and progress in South Africa required that all her people work together.

The ministry of Beyers Naudé resulted in him receiving awards and honours in SA and abroad. The academic honours included nine honorary doctoral degrees (between 1972 and 2000) from universities (Pauw 2005:21). Apart from the aforementioned honours, Beyers Naudé was also awarded the Reinhold Niebuhr Award for 'steadfast and self-sacrificing services in SA for justice and peace'. He was also awarded the prize for reconciliation and development from the Swedish Free Church and an award from the Bruno Kreisky Foundation in recognition of his 'uniting work in race relation' (www.anc.org.za). The Afrikaans Taal en Kultuur Vereeniging (ATKV) awarded him their highest award for nation-building in 2004. He also received the freedom of the city of Johannesburg in 2001 (ibid).

Additionally, the ministry of Beyers Naudé also resulted in the victims of apartheid naming institutions and other structures after him as a symbol of honour and gratitude. For instance, one of the main streets in Johannesburg, D.F. Malan, was re-named after him as Beyers Naudé Drive (The
Star). Apart from this there is a Beyers Naudé Square in Johannesburg that was also named after him. The University of Stellenbosch named their Centre for Public Theology after him (Pauw 2005:21).

The ministry of Beyers Naudé also resulted in authors writing works in dedication and honour of him. In 1982, Peter Randall produced a book entitled Not Without Honour. Tribute to Beyers Naudé. This work was about essays in honour of Beyers Naudé. Four years later, in 1986, the World Council of Churches (WCC) published a book entitled Hope for Faith. A Conversation. This book was about the interview conducted between Beyers Naudé and Dorothee Solle, a German theologian who taught at Union Theological Seminary in New York. This publication is also available in video format. Almost ten years later, in 1995, a Festchrift was published entitled Many Cultures, One Nation. A Festchrift of Beyers Naudé. This work was edited by Prof. Charles VillaVincecio and Carl Niehaus. In 2004 another work about Beyers Naudé was produced by a doctoral student of the University of Pretoria, Dr M. Heaney. This thesis was entitled Beyers Naudé, Ekumeniese Baanbreker in Suid Afrika: 1960-1994 (Beyers Naudé, Ecumenical Pioneer in South Africa: 1960-1994). One year later, in 2005, Colleen Ryan produced a book about the life of Naudé titled Beyers Naudé Pilgrim of Faith.

\section{Diminishing prophetic voice of the church in post-Beyers Naudé period}

In order to understand the difference in prophetic ministry between the churches of Beyers Naudé's time and post-1994, it is important to first outline the picture of the prophetic ministry during his ministry period. Churches during this period were prophetic and judged by their approach to the injustices of apartheid. For instance, their prophetic voices became loud from the beginning of the official start of apartheid in 1948. De Gruchy (1986:88) noted this trend when he stated: 'Since 1948, the synods, conferences, and assemblies of the churches have protested against every piece of legislation they have considered unjust ...'.

The level of prophetic ministry differed from church to church. The difference became apparent amongst Christian communities in their interpretation of scripture regarding apartheid. For instance, 'some regard racial separation as scriptural, some as blatantly unscriptural, and others as pragmatically necessary but not ideal' (De Gruchy 1986:58). Most English speaking churches were more prominent than others in their prophetic ministry. For instance, the General Assembly of the Presbyterian Church of South Africa in September 1948 'criticised proposed legislations aimed at depriving Africans of their limited Parliamentary representation as a retrograde step contrary to the claims of the Christian responsibility' (De Gruchy 1986:54). The General Assembly's prayer was 'that white South Africans may be saved from the contempt in the eyes of the world which such actions is bound to produce' (ibid). During the same period, the Methodist Church of Southern Africa also 
had a conference which released a statement that declared its position regarding racism:

(...) no person of any race should be deprived of constitutional rights or privileges merely on the grounds of race and morally binding contracts protecting such rights or privileges should be regarded on a high level of a pledged word. (De Gruchy 1986:54)

Another church that added her voice against apartheid was the Congregational Assembly which wrote, 'It is our sincere conviction that the Government's policy of apartheid has no sanction in the New Testament Scriptures (...)' (De Gruchy 1986:54).

The most formidable response against apartheid came from the Anglican Church of South Africa. The Episcopal Synod of the Church of the Province of South Africa issued a statement as early as 1948 in which they indicated that they identified themselves with the Lambeth Conference that declared 'that discrimination between men on the grounds of race alone is inconsistent with the principles of the Christian religion' (De Gruchy 1986:55).

This church action against apartheid could also be seen in the activities of the Anglican missionary, Father Trevor Huddleston who worked in Sophiatown in Johannesburg (De Gruchy 1986:60). The critical role played by Father Huddleston against racial discrimination in South Africa could be seen in the way Smith (in De Saintonge 1989:41) referred to him as, 'that turbulent priest from the Community of the Resurrection, who has been a thorn in the flesh of the present regime for the last forty years or more'.

In the light of the aforementioned picture, if apartheid with all its injustices was the focus of the churches' prophetic ministry, what are the main challenges today? The 'apartheid' of today is poverty, corruption, xenophobia, unethical utterances by politicians and a lack of political tolerance as seen from the torture and humiliation of non-striking workers. General moral decline in society as shown by rape cases, extra-marital relationships, prostitution, the highlevel of divorce and subtle-racism are a matter of concern. Churches are quiet about all of these issues. Even the South African Council of Churches that used to be vocal during the period under review is now silent.

A point that silenced the church from effectively ministering to the victims of oppression is the close relationship that exists between individual religious leaders and the post1994 democratic government. Religious leaders who used to exercise their prophetic ministry during the apartheid government are today in the employ of the democratic government, occupying senior positions. This trend silenced them and they became recipients of petitions from victims of oppression during protest marches. They stand against the victims of oppression, taking the side of the state.

The church is expected to be prophetic at all times. Unfortunately, in the post Beyers Naudé era, the church's prophetic voice has been silent. For instance, during the 2008 xenophobic violence in South Africa, the voice of the church was not heard in the way it used to speak during such incidents in the time of Beyers Naudé. During the post Beyers Naudé's ministry period, apart from the aforementioned example of xenophobia, many incidents have continued to happen, which have challenged the prophetic role of the church. Examples of these are the general decline in morals, manifesting itself in high levels of rape, torturous criminal activities and corruption, predominantly in government. The church should therefore be in a position to minister to all sectors of society including the state.

\section{Conclusion}

This article highlighted the importance of contextual theology in South Africa. The fact that Beyers Naudé's ministry addressed the conditions of people, in this case the victims of oppression, made it meaningful in their lives. It became apparent in this article that Beyers Naudé contributed considerably in areas such as his ministry by presence, reconciliation, ecumenism and interaction between church and authorities. On reconciliation he challenged people to apply action on matters of reconciliation by emphasising 'the importance of going beyond words' (in Hansen 2006:28). In the words of Pauw (2005:21), 'Naudé's name had come to stand for the process of reconciliation in a formerly divided country'. It became apparent that reconciliation cannot be organised or arranged, but is a fragile and wonderful gift from God (Meiring 1999:242). Beyers Naudé (in Clements 2006:170), on the interaction between the church and state authorities, advised that the church's prophetic ministry should not only be limited to an apartheid government, but to all governments whether democratic or not.

Beyers Naudé therefore, demonstrated and conveyed a story of a positive Christian witness in SA within the realm of Christian mission through his ministry and contribution for the victims of apartheid. The example of the ministry of Beyers Naudé is still needed today because we still have victims of oppression.

\section{Acknowledgements Competing interests}

The authors declare that they have no financial or personal relationship(s) which may have inappropriately influenced them in writing this paper.

\section{Authors' contributions}

C.J.P. (University of Pretoria) was the study leader and M.T. (University of Pretoria) made intellectual contributions.

\section{References}

Adonis, J.C., 2005, 'Dr Beyers Naudé and Church Unification in the Family of Dutch Reformed Church', in The Legacy of Beyers Naudé, Beyers Naudé Centre Series on Public Theology, Vol. 1, pp. 117-126, Sun Press, Stellenbosch.

Ackermann, D.M., 2005, 'Beyers Naudé: Public Theologian', in The Legacy of Beyers Naudé, Beyers Naudé Centre Series on Public Theology, Vol. 1, pp. 63-76, Sun Press, Stellenbosch. 
African National Congress, n.d., Beyers Naudé, viewed 08 September 2008, from www.anc.org.za

Ancer, J. \& Kgosana, C., 2004,' Oom Bey inspired us all, says Mandela', IOL News, viewed 09 September 2004, from http://www.iol.co.za/news/politics/oom-beyinspired-us-all-says-mandela-1.221482

Bevans, S.B. \& Schroeder, R.P., 2006, Constants in Context: A Theology of Mission for Today, American Society of Missiology Series, No. 30, Orbis, Maryknoll.

Bosch, D.J., 1991, Transforming Mission: Paradigm Shifts in Theology of Mission, Orbis, New York.

Clements, K.W., 2006, 'An interview with Beyers Naudé', in L. Hansen \& R. Vosloo (eds.) Oom Bey for the Future: Engaging the witness of Beyers, Naudé Beyers Naude Centre Series on Public Theology, Vol. 2, pp. 167-172, Sun Press, Stellenbosch.

De Gruchy, J., 1986, The Church Struggle in South Africa, 2nd edn., David Phillip, Claremont.

De Saintonge, R., 1989, Outside the Gate: The Story of Nico Smith, Holder and Stoughton, London.

Dubow, S., 2000, The African National Congress, Jonathan Ball, Johannesburg.

Ellis, S. \& Sechaba, T., 1992, Comrades against Apartheid: The ANC and the South African Communist Party in Exile, James Currey, London.

Hansen, L., 2006, 'Oom Bey and the youth: Three Challenges for the future', in L. Hansen \& R. Vosloo (eds.), Oom Bey for the future: Engaging the witness of Beyers Naudé, Beyers Naudé Centre Series on Public Theology, Vol. 2, pp. 21-43, Sun Press, Stellenbosch.

Hayes, T.W., 2006, 'Oom Bey for the Future: A Retrospect', in L. Hansen \& R. Vosloo (eds.), Oom Bey for the Future: Engaging the witness of Beyers Naudé, Beyers Naudé Centre Series on Public Theology, Vol. 2, pp. 47-63, Sun Press, Stellenbosch.

Heaney, M.J., 2004, 'Beyers Naudé, Ekumeniese Baanbreker in Suid-Afrika: 19601994', PhD thesis, Department Godsdiens en Sendingwetenskap, University of Pretoria, Suid-Afrika.

Hirsch, A., 2006, The forgotten ways: Reaching the missional church, Brazos, Michigan

International Defence and Aid Fund for Southern Africa, 1988, Nelson Mandela, His life in the Struggle, A Pictorial History, A.G. Bishop \& Sons, Orpington Kent (Britain).

Knitter, P.E., 1985, No Other Name: A Critical Survey of Christian Attitudes Toward the World Religions, SCM Press, London.

Meiring, P., 1999, 'Reconciliation: dream or reality?', Missionalia 27(2), 241-244.

Meyer, R.J., 2006, 'Beyers Naudé as an icon: Reflections on his role towards a new South African Society', Practical Theology of South Africa 21(3), 122-138.

Vani Nair, K., 2004,' 'Mbeki hails Naudé at his funeral', IOL News, viewed 18 September 2004, from http://www.iol.co.za/news/politics/mbeki-hails-naude-at-hisfuneral-1.222188
Naudé, C.F.B., 1995, My land van hoop: Die lewe van Beyers Naudé, Human and Rousseau, Cape Town.

Naudé Center Series on Public Theology, Vol. 1, pp. 7-24, Sun Press, Stellenbosch.

Ngcokovane, C., 1989, The Demons of Apartheid: A moral and ethical Analysis of the N.G.K, N.P. and Broederbond's justification of Apartheid, Skotaville, Braamfontein

Okoye, J.C., 2006, Israel and the Nations: A Mission Theology of the Old Testament, Orbis, New York.

Pauw, J.C., 2005, 'The Life and Legacy of Beyers Naudé', in L.D. Hansen (ed.), The Legacy of Beyers Naudé, pp. 7-24, SUN Press, Stellenbosch.

Randall, P. (ed.), 1982, Not Without Honour: Tribute to Beyers Naudé, Raval Press, Johannesburg.

Ryan, C., 2005, Beyers Naudé: Pilgrimage of faith, 2nd edn., David Philip Publishers, Claremont.

Saayman, W., 2007, Being Missionary, Being Human: An Overview of Dutch Reformed Mission, Cluster Publications, Piertermaritzburg.

Saayman, W., 2009, 'Personal Reflections: Klippies Kritzinger as I know Him', Missionalia 37(3), 12-23.

Strassberger, E., 2001, 'Ecumenism in South Africa 1936-1960 (with special reference to the church)', doctoral thesis, Department of Missiology, University of Stellenbosch, South Africa.

Tutu, D.M., 2005, 'Beyers Naudé': Unlikely Champion of Justice', in The Legacy of Beyers Naudé, Center Series on Public Theology, Vol. 1, pp. 47-53, Sun Press Stellenbosch.

World Council of Churches, 1986, C.F. Beyers Naudé, Dorothee Solle, Hope For Faith A Conversation, WCC Publications, Geneva.

\section{Pro Veritate}

Pro Veritate, 15 May 1965 (vol iv, no.1). Pro Veritate, 15 July 1965 (vol iv, no. 3). Pro Veritate, 15 May 1966 (vol. v, no. 1). Pro Veritate, 15 July 1966 (vol. v, no. 3). Pro Veritate, 15 August 1966 (vol v, no. 4). Pro Veritate, 15 September 1966 (vol v, no.5). Pro Veritate, 15 October 1966 (vol v, no. 6). Pro Veritate, 15 December 1966 ( vol v, no.8). Pro Veritate, 15 March 1967 (vol v, no.11). 